Original Research Paper

\title{
Ultrasound Imaging of the Testes and Accessory Sex Glands in Male Goat Treated with GnRH During Non-Breeding Season
}

\author{
${ }^{1}$ Hamed T. Elbaz, ${ }^{1}$ Emad M. Abdel Razek and ${ }^{2}$ Ahmed Dawod \\ ${ }^{I}$ Theriogenology Department, Faculty of Veterinary Medicine, University of Sadat City, Menofia, Egypt \\ ${ }^{2}$ Husbandry and Animal Wealth Development Department, Faculty of Veterinary Medicine, \\ University of Sadat City, Menofia, Egypt
}

Article history

Received: 04-02-2019

Revised: 25-03-2019

Accepted: 11-04-2019

Corresponding Author:

Ahmed Dawod

Husbandry and Animal Wealth

Development Department,

Faculty of Veterinary Medicine,

University of Sadat City,

Menofia, Egypt

Email: adawod1980@gmail.com

\begin{abstract}
The aim of the present study was to determine the effect of GnRH on the measurements of testes, accessory sex glands and testosterone hormonal concentrations during the non-breeding season. Eight mature healthy Egyptian Baladi male goat injected with Buserelin acetate (GnRH analogue) $8 \mu \mathrm{g}$ once weekly for one month. Ultrasonographic measurements of the scrotum and its contents and all accessory sex gland and blood samples collection were done one week before experiment and one week after the end of experiment. Results revealed that scrotal circumference, length and breadth of both testes did not differ significantly $(\mathrm{p}>0.05)$. While, the length and breadth of the tail of epididymis was increased significantly after treatment $(p<0.05)$. The length and breadth of vesicular gland and bulbourethral gland differed significantly $(\mathrm{p}<0.05)$ after treatments. The ampulla and pars disseminata of prostate breadth was increased significantly $(p<0.05)$. Treated bucks showed higher values for serum testosterone after treatment. In conclusion, the present results demonstrated that $\mathrm{GnRH}$ injection ameliorates male goat reproductive efficiency. Moreover, ultrasonography is an affirmative indicator to the response of male reproductive system to exogenous $\mathrm{GnRH}$ analogue treatment during the non-breeding season.
\end{abstract}

Keywords: Bucks, GnRH, Testosterone, Ultrasonography

\section{Introduction}

Male reproductive efficiency may be enhanced by melatonin treatment (Rosa et al., 2000), or by applying artificial lighting regimes (Delgadillo et al., 2004).The eCG injections stimulate testosterone secretion and testicular activity in rams (Hochereau-De et al., 1990; Price et al., 1991). There was a strong relation between testis volume and serum testosterone concentration after injection of GnRH in male animals (Schanbacher and Lunstra, 1977; Anderson, 1992; Gabor et al., 1995). On the contrary, Schneider et al. (1998) stated that prolonged administration GnRH resulted in decreasing of spermatogenesis, reduced the size and testicular volume. FSH can stimulate the testicular activity through its receptors on leydig cells, sertoli cells and peri-tubular myoid cells (Walker and Cheng, 2015). Rams administrated with two doses of eCG before joining with anestrous ewes, stimulate their ability to induce ewes reproductive activity and enhance the ram effect by increasing androgen hormone (Ungerfeld et al., 2014). Long-term treatment of GnRH at lower doses had a stimulatory effect on the pituitary gland and indirectly affects gonadal function but in large doses have a depressive effect on prostate, testis and vesicular glands (Warner et al., 1983). The non-breeding season can affect the reproductive pattern of rams desire, sexual activity, androgen concentration, testicular volume and semen parameters (Avdi et al., 2004; Dufour et al., 1984; Gündogan, 2007). Reproductive efficiency in bucks considered as seasonal breeding and reliant on breed and geographical distribution (Fatet et al., 2011). Seasonal variations in testicular measuraments have been described in many ram breeds (Dickson and Sanford, 2005). Testicular measuraments can be changed by photoperiod, Season, temperature and relative humidity 
(Pelletier et al., 1982; Rosa et al., 2000). When the day light was decreased the testes and spermatogenesis reach their peak activity during the autumn season (Lincoln, 1998).on the other hand, season can ameliorates androgen secretion (Kafi et al., 2004), improve the testicular hemodynamics with changes in circulating androgen and estrogen in Shiba goats (Samir et al., 2018). Testicular echogenicity, FSH concentration and thyroid hormone can be used for puberty judgement (Bartlewski et al., 2017). Ultrasound can be used in the visualization the scrotal contents (Ragheb and Higgins, 2002; Ahmadi et al., 2012) and seminiferous tubules lumination (Giffin et al., 2014). Assessment of actual testicular dimensions in male goat can be done by ultrasonography (Samir et al., 2015). Therefore, the aim of the present study is to evaluate the effect of the Buserelin acetate (GnRH analogue) injections on the measurements of testes, epididymis, accessory sex glands and some hormonal parameters during the non-breeding season of Baladi male goat with the help of ultrasound.

\section{Materials and Methods}

\section{Animals}

The present study was carried out on a total number of eight adult bucks (Egyptian Baladi male goat) belonged to the educational farm, Faculty of Veterinary Medicine, Sadat City University, Egypt. Bucks aged between 2 and 2.5 years and averaging (40-50) $\mathrm{kg}$ body weight during the period from (May to June, 2017). All bucks were apparently normal, housed in free stall barn and fed a balanced ration (14\% crude protein, $15 \%$ crude fiber, $9 \%$ ash and $2 \%$ fat), as well as free access of the drinking water and green fodders (Alfalfa).

\section{Experimental Design}

Animals $(n=8)$ was injected with Buserelin acetate (GnRH analogue) (2 ml IM from Receptal ${ }^{\circledR}$, Intervet, International B.V. European Union (EU)), each buck injected with a dose of $8 \mu \mathrm{g}$ once weekly for one month. Ultrasound examination and blood sampling of all animals were done one week before experiment and one week after the end of experiment.

\section{Testis Measurement}

Scrotal circumference was measured by measuring steel tape (Ahmed and Noakes, 1995). Testis length was measured from top of the tail to the head of the epididymis for each testis using caliper (Islam and Land, 1977). All testes length was done for both right and left one.

\section{Ultrasonographic Measurements of Reproductive Organs}

Ultrasonographic imaging of the testes and epididymis were done in the standing position. An ultrasound examination of bucks was done by means of 5-7.5 MHz linear probe of Scanner (Sonoscape-A5V, Shenzhen, China) per scrotal cutaneous to investigate the testis, epididymis and spermatic cord according to method previously described (Gouletsou et al., 2003) one week before and one week after the end of experiment and the measurements were recorded for each side. Ultrasonographic imaging of the accessory sex glands including ampulla, vesicular, prostate and bulbourethral glands were scanned per rectum using ultrasound scanner with 5-7.5 $\mathrm{MHz}$ linear array transrectal probe. The transducer was fitted in a selfmanufactured connector to favor its manipulation per rectum according to method previously done by (Mahmoud et al., 2013). All examinations were done by the same operator. The measurements of all accessory genital glands were recorded.

\section{Blood Sampling and Hormonal Assay}

The collected blood samples $(10 \mathrm{ml})$ from jugular vein were allowed to clot at $4{ }^{\circ} \mathrm{C}$ for $10 \mathrm{~h}$ in the refrigerator then centrifuged at $3000 \mathrm{rpm}$ for 15 minutes and the separated sera were stored at $-20^{\circ} \mathrm{C}$ until subsequent analysis. Serum (testosterone, FSH, LH) concentration was determined using ELISA kits (Calbiotech, Austin, Springer valley, CA, 91978, USA) using the micro-well method and the OD absorbance has been determined at $450 \pm 10 \mathrm{~nm}$.

\section{Statistical Analysis}

Statistical analysis was performed using (GraphPad prism 5 software Inc., La Jolla, CA). Comparison between groups was made by self-paring t-test. Results are presented as means \pm standard errors. Values of $\mathrm{p}<0.05$ were considered significant.

\section{Results}

The morphometric measures of both testes including length and scrotal circumference increased numerically not statistically after hormonal treatment $(\mathrm{p}>0.05)$. The ultrasonographic measurement of scrotum and its content as presented in (Table 1) revealed that the length, breadth of both testes increased numerically not statistically after hormonal treatment $(\mathrm{p}>0.05)$ (Fig. 1). While, the length and breadth of epididymal tail was increased significantly after treatment $(p<0.05)$ (Fig. 2). Also, there was no significant difference in measurements of the spermatic cord $(p>0.05)$. The ultrasonographic measurement of accessory sex gland and hormones concentrations as presented in (Table 2) revealed that the breadth of ampullae was increased 
significantly after hormonal treatment $(\mathrm{p}<0.05)$ (Fig. 3). There was a significant difference in length and breadth measurements of vesicular glands after treatment $(p<0.05)$ (Fig. 4). In addition, the breadth of pars disseminata of prostate gland was increased significantly $(p<0.05)$ (Fig. 5). There was a significant difference in length and breadth measurements of bulbourethral glands after treatment $(\mathrm{p}<0.05)$ (Fig. 6). Furthermore, treated bucks showed higher values for serum testosterone $(\mathrm{p}<0.05)$ (increase from $1.8 \pm 0.18$ to $3.25 \pm 0.23 \mathrm{ng} / \mathrm{ml}$ after treatment). While, FSH and LH were slightly decreased after treatment $(\mathrm{p}>0.05)$ as shown in (Fig. 7).

Table 1: Scrotal circumference $(\mathrm{cm})$ and ultrasonographic measurements $(\mathrm{mm})$ of tests, epididymal tail and spermatic cord before and after treatment (mean \pm SEM)

\begin{tabular}{lll}
\hline Item & Before treatment & After treatment \\
\hline Scrotum & & \\
Scrotal circumference $(\mathrm{cm})$ & $25.75 \pm 0.55$ & $26.25 \pm 0.61$ \\
Ultrasonographic measurements & & \\
Testes & $35.52 \pm 1.17$ & $36.2 \pm 1.27$ \\
Length right & $41.17 \pm 1.13$ & $42.10 \pm 1.17$ \\
Breadth right & $39.50 \pm 1.2$ & $40.32 \pm 0.69$ \\
Length left & $38.90 \pm 1.0$ & $39.71 \pm 1.12$ \\
Breadth left & & $23.36 \pm 0.76^{\mathrm{a}}$ \\
Epididymal tail & $22.10 \pm 1.29^{\mathrm{b}}$ & $20.05 \pm 1.3^{\mathrm{a}}$ \\
Length right & $17.20 \pm 0.64^{\mathrm{b}}$ & $24.0 \pm 1.5^{\mathrm{a}}$ \\
Breadth right & $22.96 \pm 1.64^{\mathrm{b}}$ & $17.85 \pm 0.34^{\mathrm{a}}$ \\
Length left & $16.40 \pm 0.39^{\mathrm{b}}$ & $18.5 \pm 0.96$ \\
Breadth left & & $18.61 \pm 0.55$ \\
Spermatic cord & $18.35 \pm 0.95$ & \\
Breadth right & $18.55 \pm 0.78$ & \\
Breadth left &
\end{tabular}

The values carrying different letters in the same row were statistically different $(\mathrm{p}<0.05)$.

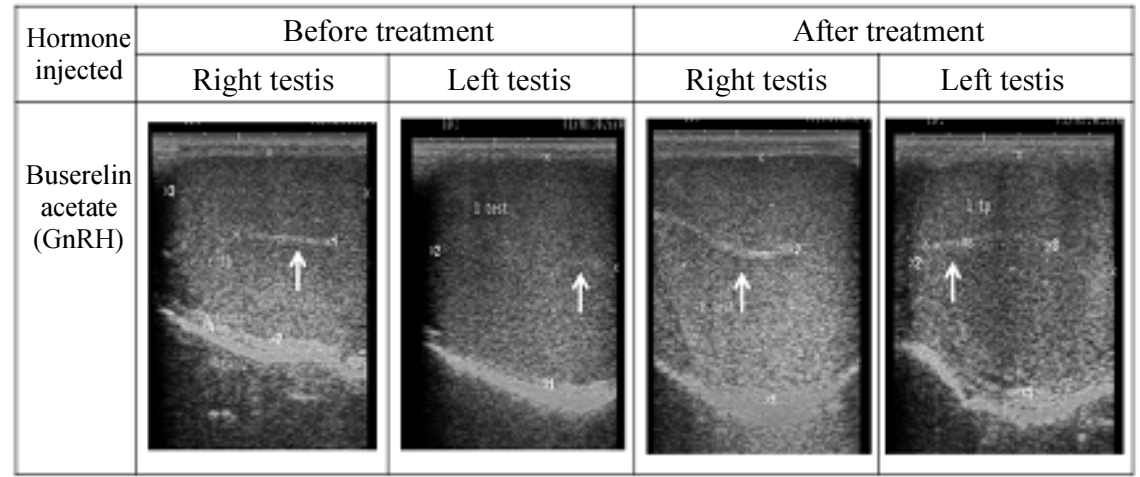

Fig. 1: Ultrasonographic image of buck's testes treated with GnRH analogue (Buserelin). No significant difference was found in length and breadth of testes and increase in echogenicity of mediastinum testes after GnRH injection (arrow)

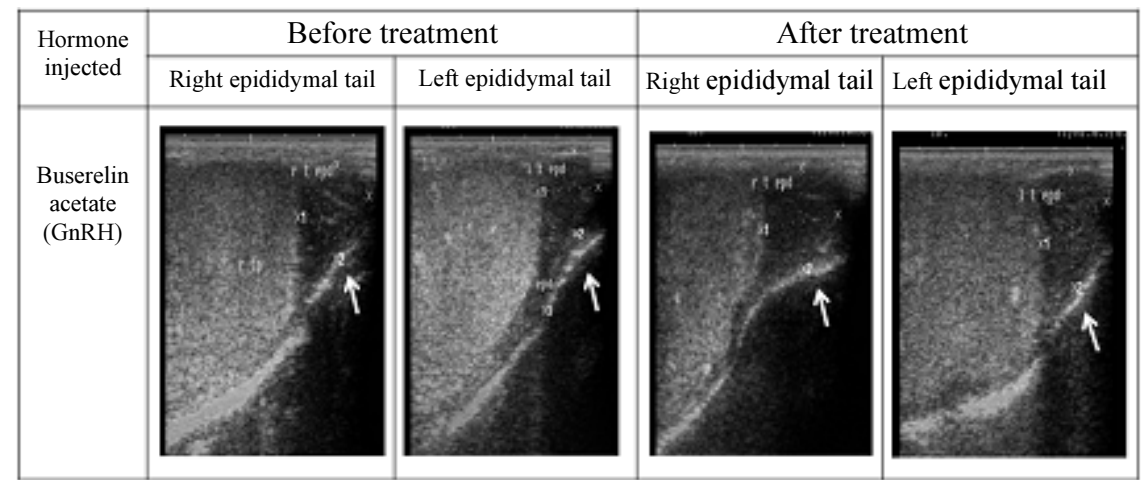

Fig. 2: Ultrasonographic image of buck's epididymal tail treated with GnRH analogue (Buserelin). Note the hypoechogenic texture and a significant increase in the epididymal tail length and breadth after GnRH injection 
Table 2: Ultrasonographic measurements of accessory sex gland $(\mathrm{mm})$ (ampulla, vesicular, p.disseminata of prostate and bulbourethral glands) and blood hormone concentrations (testosterone, FSH, LH) before and after treatment (mean \pm SEM)

\begin{tabular}{|c|c|c|}
\hline Item & Before treatment & After treatment \\
\hline \multicolumn{3}{|c|}{ Accessory genital glands } \\
\hline \multicolumn{3}{|c|}{ Ampulla } \\
\hline Diameter right & $5.1 \pm 0.32^{\mathrm{b}}$ & $5.7 \pm 0.30^{\mathrm{a}}$ \\
\hline Diameter left & $5.05 \pm 0.33^{\mathrm{b}}$ & $5.7 \pm 0.50^{\mathrm{a}}$ \\
\hline \multicolumn{3}{|c|}{ Vesicular glands } \\
\hline Length right & $25.07 \pm 1.15^{\mathrm{b}}$ & $29.5 \pm 1.72^{\mathrm{a}}$ \\
\hline Diameter right & $10.40 \pm 0.30^{\mathrm{b}}$ & $11.75 \pm 0.59^{\mathrm{a}}$ \\
\hline Length left & $22.62 \pm 1.28^{\mathrm{b}}$ & $25.47 \pm 0.91^{\mathrm{a}}$ \\
\hline Diameter left & $10.10 \pm 0.64^{\mathrm{b}}$ & $12.47 \pm 0.77^{\mathrm{a}}$ \\
\hline \multicolumn{3}{|c|}{ P.disseminata Prostate } \\
\hline Diameter & $14.10 \pm 0.39^{\mathrm{b}}$ & $14.62 \pm 0.39^{\mathrm{a}}$ \\
\hline \multicolumn{3}{|c|}{ Bulbourethral glands } \\
\hline Length right & $13.30 \pm 0.25^{\mathrm{b}}$ & $15.2 \pm 0.57^{\mathrm{a}}$ \\
\hline Diameter right & $12.07 \pm 0.56^{\mathrm{b}}$ & $14.1 \pm 0.69^{\mathrm{a}}$ \\
\hline Length left & $14.02 \pm 0.61^{\mathrm{b}}$ & $14.7 \pm 0.57^{\mathrm{a}}$ \\
\hline Diameter left & $11.92 \pm 0.47^{\mathrm{b}}$ & $12.9 \pm 40^{\mathrm{a}}$ \\
\hline \multicolumn{3}{|c|}{ Hormone concentrations } \\
\hline \multicolumn{3}{|c|}{ Testosterone $(\mathrm{ng} / \mathrm{ml})$} \\
\hline FSH (mIU/ml) & $1.84 \pm 0.18^{\mathrm{b}}$ & $3.25 \pm 0.23^{\mathrm{a}}$ \\
\hline \multirow[t]{2}{*}{$\mathrm{LH}(\mathrm{mIU} / \mathrm{ml})$} & $3.86 \pm 0.27$ & $3.65 \pm 0.21$ \\
\hline & $1.72 \pm 0.02$ & $1.68 \pm 0.03$ \\
\hline
\end{tabular}

The values carrying different letters in the same row were statistically different $(\mathrm{p}<0.05)$.

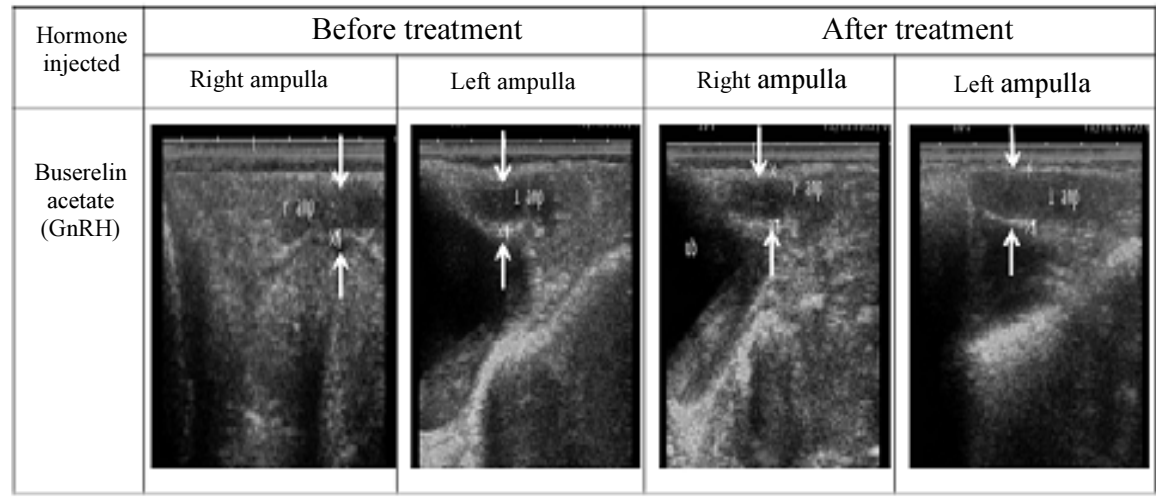

Fig. 3: Ultrasonographic image of buck's ampulla treated with GnRH analogue (Buserelin). Note the moderate non-echogenic texture and a significant increase in the breadth of ampulla after GnRH injection

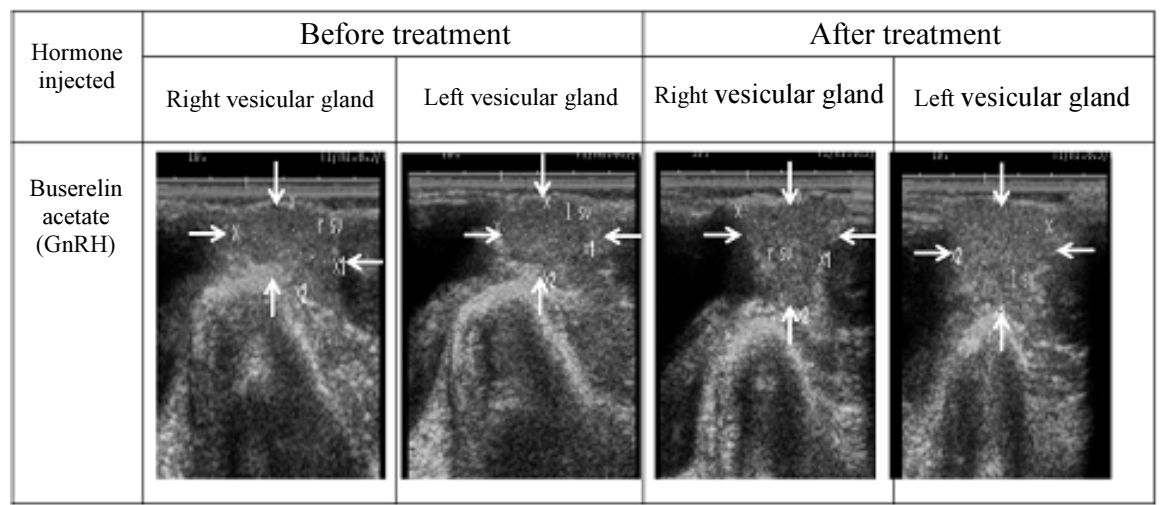

Fig. 4: Ultrasonographic image of buck's vesicular glands treated with GnRH analogue (Buserelin). Note the moderate hypoechogenic texture and a significant increase in length and breadth of vesicular glands after GnRH injection 


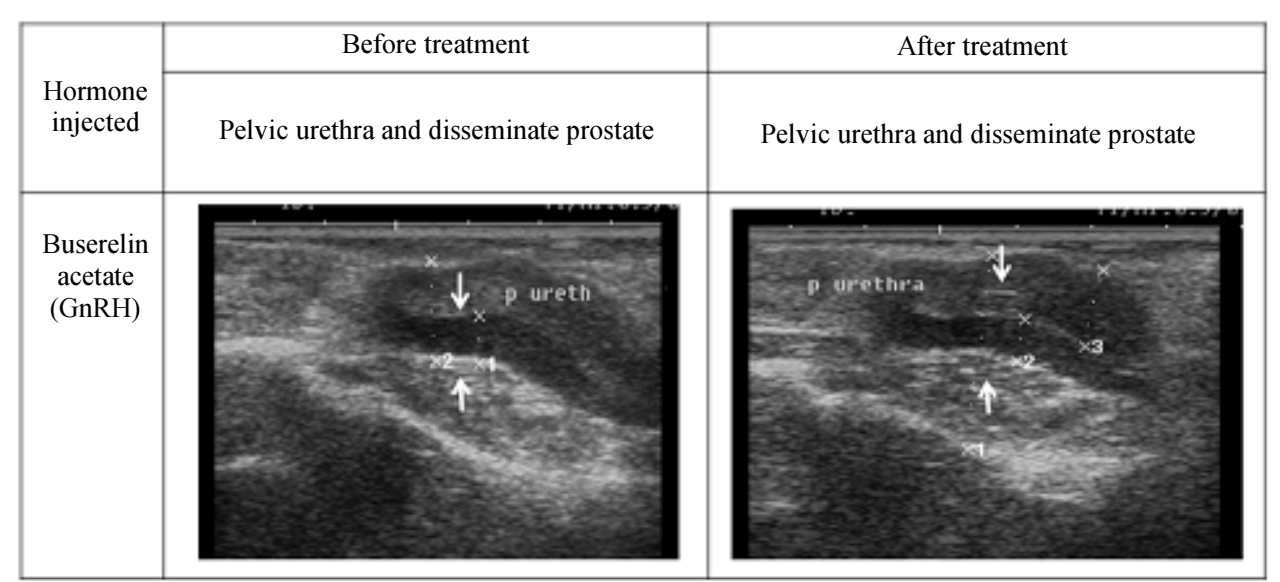

Fig. 5: Ultrasonographic image of buck's prostate gland (p. disseminata) treated with GnRH analogue (Buserelin). Note the echogenic texture and a significant increase in the breadth and echogenicity of $\mathrm{p}$. disseminata enclosing the lumen of pelvic urethra after GnRH injection (arrow)

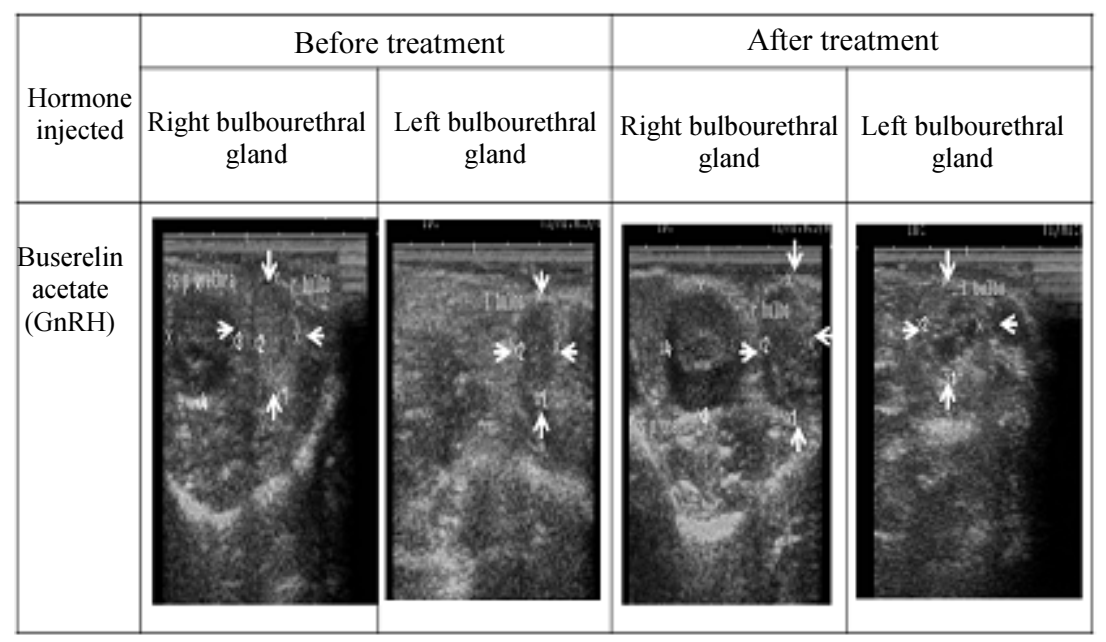

Fig. 6: Ultrasonographic image of buck's bulbourethral glands treated with GnRH analogue (Buserelin). Note the hypoechogenic texture and a significant increase in length and breadth of bulbourethral glands after GnRH injection

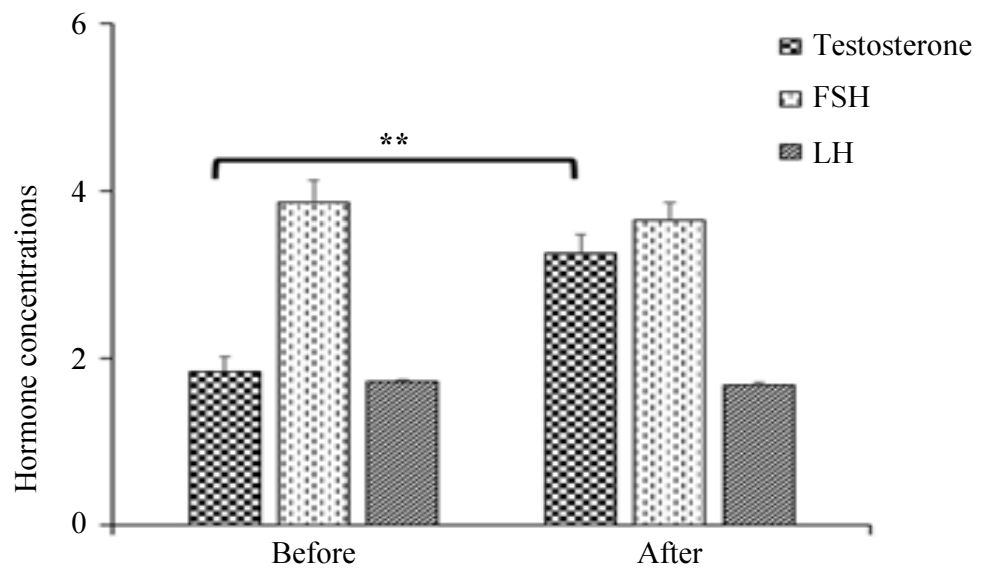

Fig. 7: Changes in serum concentration of testosterone, FSH, LH in bucks before and after treated with GnRH analogue (Buserelin).*Indicates significant difference before and after treatment $(\mathrm{p}<0.05)$ 


\section{Discussion}

Ultrasonography was a modern diagnostic device used for examination of many internal organs including its size, structure and any pathological lesions with real time images and can evaluating the response to different treatments (El-Khawaga et al., 2012). Gonadotropin releasing hormone $(\mathrm{GnRH})$ controls the activity of the gonadotrope cells of the pituitary gland which is a essential component of the endocrine cascade that determines the growth, development and functional activity of testicular tissue (Adams, 2005). In the present study the morphometric measures of both testes including length and scrotal circumference increased numerically not statistically. In accordance with the results obtained by (ElKhawaga et al., 2012) the testicular diameter did not significantly differ before and after treatment with GnRH. In the present study the ultrasonographic measurement of scrotum and its content revealed that the length and breadth of both testes increased numerically not statistically. Other results from a previous study (Medan et al., 2006) indicate that there are no variations in scrotal circumference and sperm cell concentrations between the summer and autumn in Shiba goats. Also, there was no effect on scrotal circumference and testes dimensions after GnRH injections (Ronayne et al., 1993). A finding which might be due to the short course of treatment, species difference and photoperiod.

In the present study the length and breadth of epididymal tail was increased significantly after treatment. Results from this study are in accordance with those obtained by (El-Khawaga et al., 2012) who mentioned that the stimulatory role of androgen produced from interstitial leydig cells in response to pituitary LH release following GnRH treatment. Matos and Thomas (1991) mentioned that a strong relation between testicular size with plasma FSH and testosterone concentrations. Aspden et al. (1998) Long term administration to supplemental GnRH or a potent GnRH agonist accelerate puberty in calves, increasing steroidogenic and spermatogenic activity of developing bulls.

Accessory sex glands viewed in Egyptian Baladi bucks after GnRH analogue in the current study revealed a significant difference in length and breadth measurements of (vesicular gland and bulbourethral gland) after treatment. In addition, the breadth of ampullae and pars disseminata of prostate gland was increased significantly after hormonal treatment which may be due to the higher level of serum androgen following treatment. In agreement with results obtained by (El-Khawaga et al., 2012). The growth and differentiation of accessory genital glands were mainly controlled by testosterone hormone (Risbridger and Taylor, 2006). A single injection of GnRH to yearling dairy bulls led to a distinct release of LH and androgen (Malak and Thibier, 1982). Recently, androgen and cyclooxygenase- 2 as essential regulators for the growth and secretory activity of epithelial cells in the seminal gland of bucks (Emam, 2016). While, androgen concentrations did not differ between the peri- and postpubertal rams, proposing that the size and functional activity of the accessory genital glands during that change were controlled by other factors (Camela et al., 2017). This discrepancy may be due to species difference, hormonal dose and timing of sampling. Regarding effect of GnRH on testosterone secretion, the present results showed a higher value for serum testosterone increase from $(1.8 \pm 0.18$ to $3.25 \pm 0.23 \mathrm{ng} / \mathrm{ml})$ after treatment. In accordance with the results obtained by (El-Khawaga et al., 2012) who reported that doses 8 and $12 \mu \mathrm{g}$ had a significant positive feedback on testicular hormonal secretory function of buffalo bull. In addition prolonged treatment with the GnRH agonist increase LH, FSH and testosterone concentration in prepubertal bulls (Jiménez-Severiano et al., 2003). However, the lowest testosterone value was recorded in the winter period $(2.31 \pm 0.14 \mathrm{ng} / \mathrm{ml})$ while the highest in autumn $(17.81 \pm 1.07 \mathrm{ng} / \mathrm{ml})$ (Sarlos et al., 2013). Even though, active immunization against GnRH depress synthesis of gonadotropins (LH and FSH), gonadal atrophy,affect gametogenesis, suppresses reproductive activity and form infertility of both male and female animals (Fagerstone et al., 2010). The concentrations of $\mathrm{LH}$ and testosterone were augmented four to eight fold 12-24 h after beginning continuous treatment of a potent GnRH agonist to mature rams (Lincoln et al., 1986). Karaca et al. (2015) stated that there is a strong relationship between reduction in sexual reaction time together with the increase in androgen concentration in rams. However, other studies reported that no correlation between circulating levels of testosterone and sexual desire in rams (Moghaddam et al., 2012). FSH and LH in the current study were slightly decreased after GnRH treatment. Xu et al. (1993) reported that there was a difference between groups in the pattern of seasonal variation in the total $\mathrm{LH}$ response to GnRH.Also, Bhasin and Swerdloff (1986) revealed that treatment of males with GnRH agonists causes a down-regulation of anterior pituitary gland which was associated with absence of pulsatile secretion of LH and FSH. Also, Ronayne et al. (1993) the continuous treatment of GnRH analogue to 5-month old bulls for 28 or 56 day forming increase in testosterone secretion and reduction in the LH. we proposed that elevated values of testosterone might generate a negative feedback mechanism on hypothalamic-pituitary-gonadal axis. The bucks used in the current study were physically mature and they were effectively monitored not to fluctuate in their body weight during this study. Therefore, the 
changes in testes, epididymis and accessory sex glands can be attributed to GnRH injection.

\section{Conclusion}

The current study indicated that GnRH administration was associated with changes in dimensions of testes, tail of epididymis and accessory sex glands (vesicular gland, bulbourethral gland) and breadth of (pars disseminata of prostate and ampulla). The initial rise in testosterone concentrations may be necessary for initiation and maintenance of spermatogenesis during non-breeding season. These results could be an important step to improve the reproductive performance in bucks during non-breeding season in Egypt.

\section{Acknowledgements}

The researchers thank the staff of educational Farm, faculty of veterinary medicine, Sadat City University, Egypt for their help for facilitating the examination of animals.

\section{Funding Information}

This research did not receive any specific grant from funding agencies in the public, commercial, or not-forprofit sectors.

\section{Author's Contributions}

Hamed T. Elbaz, Emad M. Abdel Razek and Ahmed Dawod: Conception, design and conduction of the study.

Emad M. Abdel Razek: Acquisition of data.

Hamed T. Elbaz and Ahmed Dawod: Analysis and interpretation of data.

Ahmed Dawod: Drafting the manuscript.

Hamed T. Elbaz, Emad M. Abdel Razek: Critical revision. All authors have read and approved the manuscript.

\section{Ethics}

All of the authors confirm that this article is original and no ethical issues are concerned with the present article.

\section{Disclosure Statement}

The authors warrant that there are no conflicts of interests among authors.

\section{References}

Adams, T.E., 2005. Using Gonadotropin-Releasing Hormone $(\mathrm{GnRH})$ and GnRH analogs to modulate testis function and enhance the productivity of domestic animals. Anim. Reproduct. Sci., 88: 127-139.
Ahmadi, B., C. Lau, J.L. Giffin, N. Santos and P.M. Bartlewski et al., 2012. Suitability of epididymal and testicular ultrasonography and computerized image analysis for assessment of current and future semen quality in the ram. Exp. Biol. Med., 237: 186-193.

Ahmed, N. and D.E. Noakes, 1995. Seasonal variation in testes size, libido and plasma testosterone concentration in British goat. Anim. Sci., 61: 553-559.

Anderson, M., 1992. Relationships between GnRH-induced testosterone maxima, sperm motility and fertility in Ayrshire bulls. Anim. Reprod. Sci., 27: 107-11.

Aspden, W.J., R.J. Rodgers, D.M. Stocco, P.T. Scott and N.G. Wreford et al., 1998. Changes in testicular Steroidogenic Acute Regulatory (STAR) protein, steroidogenic enzymes and testicular morphology associated with increased testosterone secretion in bulls receiving the luteinizing hormone releasing hormone agonist deslorelin. Domest. Anim. Endocrinol., 15: 227-238.

Avdi, M., G. Banos, K. Stefos and P. Chemineau, 2004. Seasonal variationin testicular volume and sexual behavior of Chios and Serres rams. Theriogenology, 62: 275-282.

Bartlewski, P.M., J.L. Giffin, O.A. Oluwole and A.C. Hahnel, 2017. Prospective ultrasonographic and endocrine predictors of spermatogenic onset in ram lambs. Anim. Reproduct. Sci. 179: 44-48.

Bhasin, S. and R.S. Swerdloff, 1986. Mechanisms of gonadotropin-releasing hormone agonist action in the human male. Endocr. Rev., 7: 106-114.

Camela, E.S.C., R.P. Nociti, V.J.C. Santos, B.I. Macente and G.S. Maciel et al., 2017. Ultrasonographic characteristics of accessory sex glands and spectral Doppler indices of the internal iliac arteries in peri- and post-pubertal Dorper rams raised in a subtropical climate. Anim. Reproduct. Sci., 184: 29-35.

Delgadillo, J.A., G. Fitz-Rodríguez, G. Duarte, F.G. Véliz and E. Carrillo et al., 2004. Management of pho-toperiod to control caprine reproduction in the subtropics. Reprod. Fertil. Dev., 16: 471-478.

Dickson, K.A. and L.M. Sanford, 2005. Breed diversity in $\mathrm{FSH}, \mathrm{LH}$ and testosterone regulation of testicular function and in libido of young adult rams on the south eastern Canadian prairies. Small Rumin. Res., 56: 189-203.

Dufour, J.J., M.H. Fahmy and F. Minvielle, 1984. Seasonal changes in breedingactivity, testicular size, testosterone concentration and seminal characteristics in rams with long or short breeding season. J. Anim. Sci., 58:416-422.

El-Khawaga, A.R.M., M.M. Kandiel, G.A. Sosa, A.M.E El-Roos and A.E. Abdel-Ghaffar et al., 2012. Ultrasound imaging of the testes and accessory sex glands in buffalo bulls treated with gonadotrophic releasing hormone. J. Reprod.Infertility 3: 08-16. 
Emam, M.A., 2016. Expression of androgen receptor and cyclooxygenase-2 in the vesicular glands of castrated and intact goat. Acta. Histochemica, 118: 129-136

Fagerstone, K.A., L.A. Miller, G. Killian and C.A. Yoder, 2010. Review of issues concerning the use of reproductive inhibitors, with particular emphasis on resolving human-wildlife conflicts in North America. Intergr. Zool., 5: 15-30.

Fatet, A., M.T. Pellicer-Rubio and B. Leboeuf, 2011. Reproductive cycle of goats. Anim. Reprod. Sci., 124: 211-219.

Gabor, G., M. Mezes, J. Toser, S. Bozo and E. Szues et al., 1995. Relationship among testosterone response to GnRH administration, testis size and sperm parameters in Holstein-Friesian bulls. Theriogenology, 43: 1317-1327.

Giffin, J.L., P.M. Bartlewski and A. Hahnel, 2014. Correlations among ultrasonographic and microscopic characteristics of prepubescent ram lamb testes. Exp. Biol. Med., 239: 1606-1618.

Gouletsou, P.G., G.S. Amiridis, P.J. Cripps, T. Lainas and K. Deligiannis et al., 2003. Ultrasonographic appearance of clinically healthy testicles and epididymides of rams. Theriogenology, 59: 1959-1972.

Gündogan, M., 2007. Seasonal variation in serum testosterone, T3 and andrological parameters of two Turkish sheep breeds. Small Rumin. Res., 67: 312-316.

Hochereau-De, R.M.T., M. Copin, M. Seck, C. MonetKuntz and M. Boomarov et al., 1990. Stimulation of testosterone production by PMSG injection in the ovine male: effect of breed and age and application to males carrying or not carrying the " $F$ " Booroola gene. Anim. Reprod. Sci., 23: 21-32.

Islam, A.B.M. and R.B.C. Land, 1977. Seasonal variations in testes diameter and sperm output of rams of breeds of different prolificacy. Anim. Prod., 25: 311-317.

Jiménez-Severiano, H., M.J. D'Occhio, D.D. Lunstra, M.L. Mussard and J.W. Koch,et al., 2003. Effect of chronic treatment with gonadotrophin-releasing hormone agonist azaglynafarelin on basal concentrations of $\mathrm{LH}$ in prepubertal bulls. Reproduction, 125: 225-232.

Kafi, M., M. Safdarian and M. Hashemi, 2004. Seasonal variation in semen characteristics, scrotal circumference and libido of Persian Karakul rams. Small Rumin. Res., 53: 133-139.

Karaca, S., S. Erdo-gan and A. Yilmaz, 2015. Relationship between sexual behaviors and serum testosterone concentrations in Norduz rams. Hayvansal Uretim, 56: 8-13.
Lincoln, G.A., 1998. Reproductive seasonality and maturation throughout the complete life-cycle in the mouflon ram (Ovis musimon). Anim. Reprod. Sci., 53: 87-105.

Lincoln, G.A., H.M. Fraser and M.P. Abbott, 1986. Blockade of pulsatile LH, FSH and testosterone secretion in rams by constant infusion of an LHRH agonist. J. Reprod. Fertil., 77: 587-597.

Mahmoud, G.B., S.M. Abdel-Raheem and H.A. Hussein, 2013. Effect of combination of vitamin $\mathrm{E}$ and selenium injections on reproductive performance and blood parameters of Ossimi rams. Small Ruminant Res., 113: 103-108.

Malak, A.G. and M. Thibier, 1982. Plasma LH and testosterone responses to synthetic Gonadotropin Releasing Hormone (GnRH) or dexamethason-GnRH combined treatment and their relationship to semen output in bulls. J. Reproduct. Fertility, 64: 107-113.

Matos, C.A.P. and D.L. Thomas, 1991. Physiology and genetics of testicular size in sheep: a review. Livest. Prod. Sci. 32: 1-30.

Medan, M.S., G. Watanabe, Y. Nagura, M. Fujita and K. Taya, 2006. Effect of active immunization against inhibin on hormonal concentrations and semen characteristics in Shiba bucks. Theriogenology, 65: 691-702.

Moghaddam, G., M.M. Pourseif, R. Asadpour, S.A. Rafat and R. Jafari-Jozani, 2012. Relationship between levels of peripheral blood testosterone, sexual behavior, scrotal circumference and seminal parameters in crossbred rams. Acta Sci. Vet., 40: 1049.

Pelletier, J., D.H. Garnier, D.M.M. Reviers, M. Terqui and R. Ortavant, 1982. Seasonal variation in LH and testosterone release in rams of two breeds. J. Reprod. Fertil., 64: 341.

Price, C.A., N.L. Hudson, K.P. McNatty and L.H. Plasma, 1991. FSH and testos-terone concentrations in adult rams which were homozygous carriersor non-carriers of the Booroola fecundity gene. J. Reprod. Fertil., 91: 267-275.

Ragheb, D. and J.L. Higgins, 2002. Ultrasonography of the scrotum:technique, anatomy and pathologic entities. J. Ultrasound Med., 21:171-185.

Risbridger, G.P. and R.A. Taylor, 2006. Physiology of the Male Accessory Sex Structures: The Prostate Gland, Seminal Vesicles and Bulbourethral Glands. 3rd Edn. Elsevier.

Ronayne, E., W.J. Enright and J.F. Roche, 1993. Effects of continuous administration of GonadotropinReleasing Hormone (GnRH) or a potent GnRH analogue on blood luteinizing hormone and testosterone concentrations in prepubertal bulls. Domestic Anim. Endocrinol., 10: 179-189. 
Rosa, H.J.D., D.T. Juniper and M.J. Bryant, 2000. Effects of recent sexualexperience and melatonin treatment of rams on plasma testosteroneconcentration, sexual behaviour and ability to induce ovulation inseasonally anoestrous ewes. J. Reprod. Fertil., 120: 169-176.

Samir, H., K. Sasaki, E. Ahmed, A. Karen and K. Nagaoka et al., 2015. Effect of a single injection of Gonadotropin-Releasing Hormone (GnRH) and Human Chorionic Gonadotropin (hCG) on testicular blood flow measured by color Doppler ultrasonography in male Shiba goats. J. Vet. Med. Sci., 77: 549-56.

Samir, H., P. Nyametease, K. Nagaoka and G. Watanabe, 2018. Effect of seasonality on testicular blood flow as determined by color Doppler ultrasonography and hormonal profiles in Shiba goats. Anim. Reproduct. Sci., 197: 185-192.

Sarlos, P., I. Egerszegi,O. Balogh,A. Molnar and S. Cseh et al., 2013. Seasonal changes of scrotal circumference, blood plasma testosterone concentration and semen characteristics in Racka rams. Small Ruminant Res., 111: 90- 95.
Schanbacher, B.D. and D.D. Lunstra, 1977. Acute and chronic effects of gonadotropin releasing hormone on reproductive characteristics of rams during the nonbreeding season. J. Anim. Sci., 44: 650-655.

Ungerfeld, R., N. Clemente, L. Bonjour and A. Orihuel, 2014. Equine chorionic gonadotrophin administration to ramsimproves their effectiveness to stimulate anoestrous ewes (the "ram effect"). Anim. Reproduct. Sci. 149: 194-198.

Walker, W.H. and J. Cheng, 2015. FSH and testosterone signaling in Sertoli cells. Reproduction, 130: 15-28.

Warner, B., T.J. Worgul, J. Drago, L. Demers and M. Dufau et al., 1983. Effect of very high dose Dleucine 6-gonadotropin-releasing hormone proethylamide on the hypothalamic pituitary testicular axis in patients with prostatic cancer. J. Clinical Investigat., 71: 1842-1853.

Xu, Z.Z., M.F. McDonald, S.N. McCutcheon and H.T. Blair, 1993. Testis size, gonadotrophin secretion and pituitary responsiveness to $\mathrm{GnRH}$ in Romney rams during the transition from the non-breeding to the breeding season. Anim. Reproduct. Sci., 31: 99-111. 